\title{
Response of Malt Barley (Hordeum Distichum L) Varieties to Different Row Spacing under Contrasted Environments of North Gondar, Ethiopia
}

\author{
Amare Assefa Bogale $\left({ }^{1},{ }^{1}\right.$ Ketema Niguse, ${ }^{2}$ Awoke Wasae ${ }^{(D)},{ }^{2}$ and Shegaw Habitu \\ ${ }^{1}$ Department of Horticulture, College of Agriculture and Environmental Science, P.O. Box 90, Debark University, \\ Debark, Ethiopia \\ ${ }^{2}$ Department of Plant Science, College of Agriculture and Environmental Science, P.O. Box 90, Debark University, \\ Debark, Ethiopia \\ Correspondence should be addressed to Amare Assefa Bogale; amexsmart12@gmail.com
}

Received 3 October 2020; Revised 3 January 2021; Accepted 11 January 2021; Published 23 January 2021

Academic Editor: Wei Wu

Copyright (C) 2021 Amare Assefa Bogale et al. This is an open access article distributed under the Creative Commons Attribution License, which permits unrestricted use, distribution, and reproduction in any medium, provided the original work is properly cited.

\begin{abstract}
A field experiment was conducted in north Gondar to investigate the response of malt barley varieties to different inter-row spacing under contrasted environment. The experiment was laid out using randomized complete block design with three replications. The treatments were three different inter-row spacing (i.e., 20, 25, and $30 \mathrm{~cm}$ ), six malt barley varieties (i.e., Holker, HB1963, Sabine, Ibone174/03, EH1847, and Freygebse), and two locations (Miligebsa and Kino). The result sowed that days to $50 \%$ heading, days to $90 \%$ physiological maturity, plant height, spike length, and number of kernels per spike were significantly $(p<0.01)$ affected by the main effect of location and varieties. Similarly, effective tiller number, biomass yield, grain yield, and straw yield were significantly $(p<0.01)$ influenced by the main effect of variety, inter-row spacing, and location. Important interaction was also observed between varieties $\times$ inter-row spacing $\times$ location on days to $50 \%$ heading, spike length, biomass yield, grain yield, and straw yield. Location $\times$ variety interaction significantly influences the days to $90 \%$ physiological maturity and effective tiller number. Similar significant $(p<0.05)$ trend was also observed between varieties with inter-row spacing on effective tiller number and thousand kernel weight even at $p<0.01$ level of significance. It was found that optimization of row spacing was found to be influenced by location and varietal difference. Hence, on the basis of the result, it can be inferred that $25 \mathrm{~cm}$ row spacing combined with the varieties "HB1963," "Hollker," and "Sabine" was optimum for maximum yielding potential under potential environment (Miligebsa).
\end{abstract}

\section{Introduction}

Agriculture is the back bone of Ethiopian economy as it supports different crop and animal productions [1]. Among the crop categories, barley (Hordeum vulgareL.) is the best staple food and subsistence crop in the country. It is grown in varied environments with the altitude range from 1,500 meters above sea level (masl) to over 3,500 ma.s.l, but mainly grown from 2000 to 3000 masl [2]. It is the fourth most cultivated crop of the world [3]. In Ethiopia, it is ranked fifth following teff (Eragrostis teff), wheat (Triticumaestivum L.), maize (Zea mays), and sorghum (Sorghum bicolor) [4].
Barley is a reliable source of food in the highlands as it is produced during the main and short rainy seasons as well as under remaining moisture. It is used in different forms such as bread, injera, porridge, soup, and roasted grain and for preparing alcoholic and nonalcoholic drinks [5]. For example, Tella and Borde are traditional drinks which are prominent and best made from barley grain [5].The diversity of malt and food barley is grown by sharing comparable environments. Despite the fact that food barley is produced mainly for survival by the bucolic farm households, malt barley (Hordeum distichum L) is largely a profitable crop produced in the market (both for industrial malt grain 
production and for cottage local beer and liquor production).

The total area covered by barley in Ethiopia is $811,782.08$ hectares and total annual production of about 1,767,518.447 tons with the productivity of $2.177 \mathrm{tha}^{-1}$ in the 2018/2019 main cropping season. In addition, the total area covered by barley in Amhara Region is about 238164.36 hectares with a total production of $481,769.434$ tons, and its productivity is $2.023 \mathrm{tha}^{-1}$ [4]. According to the north Gondar zone report in the 2019 main cropping season, the total productivity of malt barley is $1.98 \mathrm{t} \mathrm{ha}^{-1}$. This indicates that the productivity level of the zone is still below the national and regional productivity levels. The main reasons for low yield of barley are as follows: low-yielding capability by farmers and cultivars; dominant varieties in use; the influence of biotic and abiotic stresses; and the minimal promotion of improved barley production technologies. Several abiotic factors have contributed to this low productivity, such as poor soil fertility; water logging, drought, frost, and soil acidity; humble crop management practices; use of naturally low yield potential of the predominant local varieties; and limited availability of the very few better-quality cultivars released and low level of technology [6]. Climatic factors, such as moisture and temperature, are also among the major abiotic environmental causes that are limiting the malt barley production [7]. Biotic stresses such as disease, insect pests, and weeds are the main constraints for the malt barley production in Ethiopia [8]. Beside these, the other major constraints for malt barley grain production include adaptation of the current malt barley varieties to higher elevation and specific agroclimatic zones. Even among the high-potential areas producing malting barley, poor crop management which is based on cultural practices and poorquality of the varieties used lead to the yield of poor-quality grains (i.e., screen loss, low protein content, and kernel weight 1000 [9]).

Row spacing is an essential agronomic attribute which can improve the productivity of the crops. Narrow row spacing enhances the drought tolerance by reducing evaporation losses, because evaporation from the soil depends upon the cover of bare soil exposed to sun [10]. A recent study reported that wheat sown in $20-\mathrm{cm}$ spaced rows gave higher yield than $25-$ and $30 \mathrm{~cm}$-spaced rows [10]. However, rhizosphere exploitation and photosphere affect the plants particularly when row spacing is insufficient and the plants dance together [11]. Likewise, narrow spacing impedes the agronomic practices, and in the closely populated plants, the competition of air, nutrients, and light is very high. When an inter-row distance is very large, plants cannot utilize sun light, and this reduces the yield and yield traits [12]. Consequently, optimum plant density ensures that the plants grow properly with their aerial and underground parts by utilizing more sunlight and soil nutrients, respectively [13].

In north Gondar zone, malt barley is a highly potential crop that is produced by smallholder farmers. However, there is a trend of farmer's using the broadcasting sowing method and local malt barley variety in the study area. Hence, it is important to determine optimum inter-row spacing for released malt barley varieties for the maximum yield of the crop under contrasted environment. This study is, therefore, carried out (i) to evaluate the response of malt barley varieties to different row spacing on the growth, yield, and yield components in contrasted environment and (ii) to determine the optimum row spacing for maximum productivity of malt barley varieties.

\section{Materials and Methods}

2.1. Description of the Experimental Site. The rain-fed field experiment was conducted at Kino and Milligebse Keble farmers' farm station in Debark district, north Gondar zone , Amhara National Regional State, during the 2019 main cropping season to investigate the response of malt barley varieties to different row spacing under contrasted environment. The Kino experimental site is situated at $13^{\circ} 4^{\prime} 51^{\prime \prime}-13^{\circ} 4^{\prime} 52^{\prime \prime}$ N-latitude and $37^{\circ} 53^{\prime} 17^{\prime \prime}-37^{\circ} 53^{\prime} 19^{\prime \prime} \mathrm{E}-$ longitude with an elevation of 2717 masl and Milligebsa experimental site is located at $13^{\circ} 11^{\prime} 41^{\prime \prime}-13^{\circ} 11^{\prime} 42^{\prime \prime} \mathrm{N}$-latitude and $37^{\circ} 59^{\prime} 2^{\prime \prime}-37^{\circ} 59^{\prime} 3^{\prime \prime} \mathrm{E}$ with an elevation 3153 masl (Figure 1). The average annual temperature is $12.4^{\circ} \mathrm{C}$. Based on the meteorological data, the annual rainfall is $974 \mathrm{~mm}$. The rainy season occurs during June to September, and the maximum rain is received in the month of July and August.

2.2. Materials Used in the Experiment. Six malt barley varieties (HB1963, EH 1847, Sabine, Ibone174/03, Freygebse, and Holker) were obtained from the Adet Agriculture Research Center. The varieties have different maturity dates on an average of 130 days and different ecological requirements [14]. Urea $(46 \% \mathrm{~N})$ and NPS $\left(19 \% \mathrm{~N}, 38 \% \mathrm{P}_{2} \mathrm{O}_{5}\right.$, and $\left.7 \% \mathrm{~S}\right)$ are used as sources of $\mathrm{N}, \mathrm{P}$, and $\mathrm{S}$, respectively.

2.3. Treatments and Experimental Design. The treatments consisted of three row spacing $(20,25$, and $30 \mathrm{~cm})$ and six malt barley varieties (Holker, HB1963, Sabine, Ibone 174/03, EH1847, and Freygebse). The experiment was laid out as a randomized complete block design (RCBD) in a factorial arrangement and replicated three times. The gross plot size was $1.8 \mathrm{~m} \times 2 \mathrm{~m}\left(3.6 \mathrm{~m}^{2}\right)$ row spacing as per the treatment. The net plot size varies with the row spacing: $1.4 \mathrm{~m} \times 1.6 \mathrm{~m}$ $\left(2.24 \mathrm{~m}^{2}\right), \quad 1.3 \mathrm{~m} \times 1.6 \mathrm{~m} \quad\left(2.08 \mathrm{~m}^{2}\right), \quad$ and $\quad 1.2 \mathrm{~m} \times 1.6 \mathrm{~m}$ $\left(1.92 \mathrm{~m}^{2}\right)$ for $0.2 \mathrm{~m}, 0.25 \mathrm{~m}$, and $0.3 \mathrm{~m}$ row spacing, respectively, by leaving one outermost row of both sides of each plot and $0.2 \mathrm{~m}$ row length at both ends as border. The distance between the plots and blocks was $0.5 \mathrm{~m}$ and $1 \mathrm{~m}$ apart, respectively.

2.4. Experimental Procedure or Crop Husbandry. The land was prepared following the conventional tillage practice by using oxen-driven local plow (Maresha) before planting the malt barley varieties. Accordingly, the field was ploughed four times; the last ploughing was used for sowing in accordance with the specifications of the design. After the seed beds were leveled and compacted, the recommended malt barley variety seed rate $\left(125 \mathrm{~kg} \mathrm{ha}^{-1}\right)$ was sown by drilling in each plot at the row spacing of 20,25 , and $30 \mathrm{~cm}$ as per 


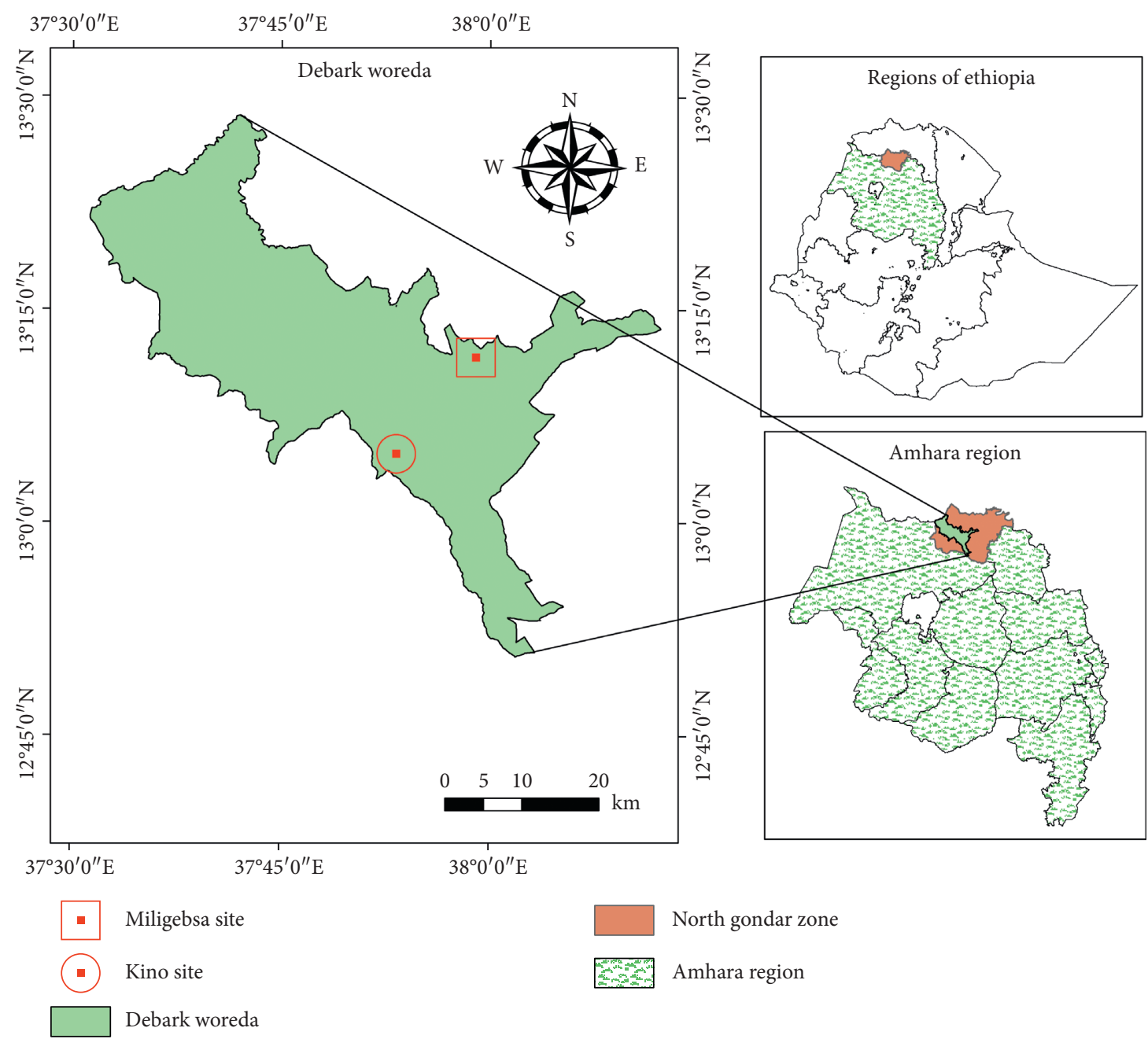

Figure 1: Map of the study area: Amhara National Regional State in Ethiopia, north Gondar in Amhara region, Debark district in north Gondar, Kino and Miligebsa Keble in Debark district.

treatment. The crop was fertilized with $100 \mathrm{~kg}$ nitrogen $(\mathrm{N})$ and $100 \mathrm{~kg}$ phosphorus $(\mathrm{P})$ using urea and diammonium phosphate as source. Total phosphorus $(\mathrm{P})$ and one-thirds of the nitrogen fertilizer $(33 \mathrm{~kg} \mathrm{~N})$ were applied as basal dose, while remaining $67 \mathrm{~kg} \mathrm{~N}$ was applied 30 days after crop sowing. The crop was weeded by hand weeding for 3 times, and harvesting was done at the physiological maturity of the crop.

2.5. Data Collection and Measurements. Each crop growth, yield, and yield components were measured from each net plot across the treatment level by using the following sampling procedures. Days to heading were recorded by counting the number of days from the date of sowing until when $50 \%$ of the plants in a plot produced spikes above the sheath of the flag leaf which was determined by visual observation. Likewise, days to physiological maturity was recorded by counting the number of days from date of sowing until when $90 \%$ of the plants changed green color to yellowish, lost its water content, and attained physiological maturity in each plot. Plant height was measured from 10 randomly selected plant samples from the middle rows of each plot as the height from ground level to the tip of the spike excluding the crowns. It was recorded as the average of ten selected main tillers from each plot at maturity across the treatment level. Similarly, the main spikes from the ten sample plants were measured in centimeters, and the average represents the spike length in centimeters for each plot across the treatment level. The number of productive (fertile) tillers bearing spikes was counted from the middle two rows which are $0.5 \mathrm{~m}$ in length at physiological maturity. The number of kernels per spike from the ten randomly selected plants from the middle rows of each plot was taken, and the average represents the number of kernels per spike for each plot across the treatment level. Thousand grains weight were counted after harvesting of the crop from each plot and measured by a sensitive balance. The crop was manually harvested from each net plot, sun-dried total aboveground crop biomass for five days, and after that, total biomass or biological yield were measured by weighing the sun-dried total aboveground crop biomass of the net plot. Threshing was done manually to separate the grains; the grain yield was measured by 
taking the weight of the grains from the net plot area. Straw yield was computed by subtracting grain yield from total aboveground sun dried biomass yield.

2.6. Statistical Analysis. Data were subjected to analysis of variance using the general linear model (GLM) procedure of SAS 9.2 version [15]. Whenever treatment difference was found to be significant among the treatment, it was compared using a list significant difference (LSD) test at 5\% level of significance. Correlation analysis was carried out by calculating simple correlation coefficients between yield and yield components.

\section{Results and Discussion}

3.1. Days to $50 \%$ Heading. The analysis of variance revealed that days to $50 \%$ heading was significantly $(p<0.01)$ affected by the main effect of varieties and locations, but the main effect of inter-row spacing was not significant on days to $50 \%$ heading. The interaction effect of row spacing, location, and variety was also significant $(p<0.05)$ (Table 1$)$.

The mean analysis data presented in (Table 2) showed that the longest days to $50 \%$ heading ( 88.333 days) was observed in HB1963 variety with $30 \mathrm{~cm}$ inter-row spacing at the Milligebsa study site. While the shortest (53.667 and 55.667) days was recorded on EH1847 and Ibone 174/3 varieties with $25 \mathrm{~cm}$ inter-row spacing at Kino study site, respectively. Significant difference was observed between the two locations, and the difference was more than 20 days with the same varieties (HB1963) at $30 \mathrm{~cm}$ row spacing. This is because of the agro-ecology of the Milligebsa study site; it is relatively higher in altitude and has high moisture-holding capacity as compared to that of Kino study site. Moreover, the reasons for delaying in days to $50 \%$ heading on malt barley varieties are because of the genetic characters of the varieties and also the wider inter-row spacing, given that crops can get enough amount of resources for growth and development; during that time, the crops may need long day to produce maximum dry matter. The current result is in agreement with that of Alemu's [16] who reported that the reason for delaying in days to $50 \%$ heading on malt barley varieties are the genetic difference of crops and adaptation to different agro-ecological zones.

However, the earliness to days to heading might be due to the competition of available nutrients at narrow space; consequently, crops cannot stay for a long period of time. This result is in line with the results reported by Adinew [17] who noted that the earliness to days to heading might be due to the higher competition to resources at narrow spacing; as a result, plants no longer need to stay in the vegetative stage.

3.2. Days to $90 \%$ Physiological Maturity. The statistical analysis indicated that days to $90 \%$ physiological maturity was significantly $(p<0.01)$ affected by the main effects of location and varieties. But, the main effect of inter-row spacing was not significant. Similarly, the interaction effect of varieties, inter-row spacing, and location was not significant (Table 1). The mean data analysis in Table 3 shows that the number of days required to $90 \%$ physiological maturity varied between 133 and 112.33 days on the main effect of varieties. The longest (133 and 130.20 ) days to $90 \%$ physiological maturity were recorded from HB1963 variety and Milligebsa study site, respectively. While the shortest (112.33 and 111.96) days required for 90\% physiological maturity were measured from Ibon 174/03 variety and Kino study location, respectively (Table 3 ). This is because of the genetic characteristics of the varieties. A similar result was observed by Terefe et al. [18] and Abtew et al. [19] who reported that genotypes might differ in days to physiological maturity. Likewise, Shahzad et al. [20] also reported that days to physiological maturity of wheat cultivars differs due to intrinsic differences between cultivars. In accordance with the present result, Geng [21] reported that the differences in maturity can be triggered by the collective effect of genetic and http://www. scialert.net/asci/result.php?searchin=Keywords\&cat=\&ascicat= ALL\&Submit=Search\&keyword=environmental+factors environmental factors during their growth and grain filling of the crops.

3.3. Plant Height. The analysis of variance showed that the main effect of variety and location significantly $(p<0.01)$ affected the plant height. However, the main effect of interrow spacing and interaction effect of varieties with interrow spacing and the three-way interaction was not significant (Table 1). The mean statistical analysis data indicated that the longest plant height $(100.6 \mathrm{~cm})$ and $(94.93 \mathrm{~cm})$ was recorded from Holker and Freygebse varieties, respectively, which are nonsignificant to each other. The shortest $(82.11$ and $85.72 \mathrm{~cm})$ plant height was recorded from Ibone174/03 and HB1963 varieties, respectively, which were statistically at par with each other. The highest $(96.20 \mathrm{~cm})$ plant height was also recorded from the Milligbsa study site, whereas the lowest $(86.337 \mathrm{~cm})$ plant height was recorded from the Kino study site (Table 3). This is because the difference of varieties might be related to difference in the plant height of malt barley with respect to the environment or location. These results agree with those of Gezahegne and Kefale [22] who reported that varietal difference in plant height might be due to genetic behavior in combination with environmental conditions. Similarly, Shahzad et al. [20] and Jemal et al. [23] also reported that the height of the crop is mainly controlled by the genetic makeup of a genotype, and it can also be affected by the environmental factors. Furthermore, Abebe [24] noted that the tallest variety mean value in plant height was recorded for Holker and the shortest variety mean value in plant height was recorded from Ibon 174/03 which might be due to the genotypic variation among varieties. In addition, Alemu [16] reported that the reasons for the variation of plant height are disparity of climatic factors, agronomic practices, crop variety, and soil fertility status of the study site; largeness in plants is frequently related to the genetic makeup of the variety [25].

3.4. Number of Kernels per Spike. Analysis of variance revealed that the main effect of variety and location on number of kernels per spike was significant $(p<0.01)$. 
TABLE 1: Mean squares of ANOVA for the effect of variety, inter-row spacing. and location on DH, DM, PH, SL, ET, NPKS, TKW, BY, GY, and SY of malt barley at Debark, north Gondar, Ethiopia, in 2019.

\begin{tabular}{|c|c|c|c|c|c|c|c|c|}
\hline \multirow[b]{2}{*}{ Parameters } & \multicolumn{7}{|c|}{ Mean square and significance level of the parameters for each source of variations } & \multirow[b]{2}{*}{$R^{2}$} \\
\hline & $\begin{array}{c}R \\
\mathrm{DF}=2\end{array}$ & $\begin{array}{c}L \\
\mathrm{DF}=1\end{array}$ & $\begin{array}{c}V \\
\mathrm{DF}=5\end{array}$ & $\begin{array}{c}\text { INR } \\
\mathrm{DF}=2\end{array}$ & $\begin{array}{l}V^{*} \text { IRS } \\
\mathrm{DF}=10\end{array}$ & $\begin{array}{c}L^{*} V^{*} \text { IRS } \\
\mathrm{DF}=10\end{array}$ & $\begin{array}{c}\text { Error } \\
\text { DF }=70\end{array}$ & \\
\hline $\mathrm{DH}$ & 2.9 & $11142.7^{* *}$ & $187.7^{* *}$ & $1.3^{\mathrm{ns}}$ & $8.8^{* *}$ & $6.8^{*}$ & 6.8 & 0.98 \\
\hline $\mathrm{DM}$ & 10.11 & $8983.56^{* *}$ & $812.68^{* *}$ & $18.36^{\mathrm{ns}}$ & $9.06^{\mathrm{ns}}$ & $7.04^{\mathrm{ns}}$ & 7.98 & 0.95 \\
\hline $\mathrm{PH}$ & 55.53 & $2628.28^{* *}$ & $793.14^{* *}$ & $113.78^{\text {ns }}$ & $55.53^{\text {ns }}$ & $83.73^{\text {ns }}$ & 81.67 & 0.60 \\
\hline SL & 0.23288 & $7.54196^{* *}$ & $1.87862^{* *}$ & $0.1504^{\mathrm{ns}}$ & $0.17772^{\mathrm{ns}}$ & $0.49823^{* *}$ & 0.14947 & 0.773133 \\
\hline ET & 359.7 & $46691.8^{* *}$ & $806.4^{* *}$ & $2491.7^{* *}$ & $280.4^{*}$ & $200.4^{\mathrm{ns}}$ & 112.4 & 0.900705 \\
\hline NKPS & 12.8744 & $25.0370^{* *}$ & $44.1713^{* *}$ & $3.6700^{\mathrm{ns}}$ & $3.0547^{\mathrm{ns}}$ & $1.8304^{\mathrm{ns}}$ & 0.88 & 0.650163 \\
\hline TKW & 33.427 & $7.895^{\mathrm{ns}}$ & $128.265^{* *}$ & $58.942^{* *}$ & $10.361^{* *}$ & $1.608^{\mathrm{ns}}$ & 3.667 & 0.786590 \\
\hline BY & 3972286 & $19783032^{*}$ & $247689^{* *}$ & $38081408^{* *}$ & $10534251^{* *}$ & $10696897^{* *}$ & 856034 & 0.976466 \\
\hline GY & 23639.9 & $54212960.49^{* *}$ & $1944383^{* *}$ & $1079136^{* *}$ & $984825^{* *}$ & $1092314^{* *}$ & 37744 & 0.975439 \\
\hline SY & 3437074 & $1377536265^{* *}$ & $18270389^{* *}$ & $27291718^{* *}$ & $6833453^{* *}$ & $5936810^{* *}$ & 866859 & 0.966151 \\
\hline
\end{tabular}

$R=$ replication, $L=$ location, $V=$ variety, $\mathrm{INR}=$ inter-row spacing, $\mathrm{DH}=$ days to heading, $\mathrm{DM}=$ days to maturity, $\mathrm{PH}=$ plant height, $\mathrm{SL}=$ spike length, $\mathrm{ET}=$ effective tiller, NKPS = number of kernels per spike, TKW $=$ thousand kernel weight, BY = biological yield, GY=grain yield, $S Y=$ straw yield, $\mathrm{DF}=$ degrees of freedom; NS, ${ }^{*}$, and ${ }^{* *}$ : nonsignificant, significantly different at $5 \%$, and $1 \%$, respectively, according to the LSD test.

TABle 2: Interaction effect of varieties, inter-row spacing, and location on days to $50 \%$ heading of malt barley at Debark, north Gondar, Ethiopia, in 2019.

\begin{tabular}{|c|c|c|c|c|c|c|c|}
\hline \multirow{3}{*}{ Location } & \multirow{3}{*}{ Inter-row spacing } & \multicolumn{6}{|c|}{ Days to $50 \%$ heading } \\
\hline & & \multicolumn{6}{|c|}{ Varieties } \\
\hline & & HB 1963 & Holker & Freygebs & Sabine & EH 1847 & Ibone 174/03 \\
\hline \multirow{3}{*}{ Milligebsa } & 20 & 85.000 & 81.000 & 80.000 & 80.000 & 83.333 & 78.000 \\
\hline & 25 & 87.667 & 82.333 & 81.333 & 81.000 & 84.0 & 78.000 \\
\hline & 30 & 88.333 & 82.333 & 82.333 & 82.000 & 85.0 & 80.667 \\
\hline \multirow{3}{*}{ Kino } & 20 & 68.000 & 65.333 & 66.333 & 63.333 & 61.333 & 57.333 \\
\hline & 25 & 67.667 & 66.000 & 63.667 & 64.000 & 53.667 & 55.667 \\
\hline & 30 & 67.667 & 64.000 & 57.667 & 62.333 & 56.667 & 56.000 \\
\hline LSD (0.05) & & & & 2.9918 & & & \\
\hline $\mathrm{CV}$ & & & & 2.54 & & & \\
\hline
\end{tabular}

LSD = list significant difference; $C V=$ coefficient of variation.

TABLE 3: Main effect of varieties and location on days to maturity, plant height, and number of kernels per spike of malt barley at Debark, north Gondar, Ethiopia, in 2019.

\begin{tabular}{lccc}
\hline Treatment & & Parameters \\
Plant height $(\mathrm{cm})$ & Number of kernels per spike \\
\hline Varieties & Days to 90\% physiological maturity & 85.72 & 27.394 \\
HB1963 & 133.0 & 100.6 & 27.089 \\
Holker & 119.39 & 91.06 & 25.156 \\
Sabine & 120.33 & 94.93 & 23.356 \\
Freygebse & 119.67 & 93.11 & 24.411 \\
EH 1847 & 121.72 & 82.11 & 24.928 \\
Ibone & 112.33 & 6.0081 & 0.9612 \\
LSD & 1.8778 & & 25.870 \\
\hline Location & & 96.20 & 24.907 \\
Milligebsa & 130.20 & 86.337 & 0.5550 \\
Kino & 111.96 & 3.4688 & 5.69 \\
LSD & 1.0841 & 9.90 & \\
CV & 2.33 & & \\
\hline
\end{tabular}

LSD = list significant difference; $C V=$ coefficient of variation.

However, the main effect of inter-row spacing, interaction effect of varieties with inter-row spacing, and the three-way interaction was not significant (Table 1 ). The variety and location mean result showed that the maximum number (27.394, 27.089) of kernels per spike was obtained from HB1963 and Holker varieties, respectively, which are not 
significant with each other, while the minimum number (23.356) of kernels per spike was recorded from Freygebse variety (Table 3 ). This might be because the genetic characteristics of different malt barley varieties give different number of kernels per spike. In case of location, the maximum number (25.870) of kernels per spike was obtained from the Milligebse study site, whereas the minimum number (24.907) of kernels per spike was recorded from the Kino study site (Table 3 ). The reason for this variation might be the environmental factors of the study site, since the altitude range of Milligebse study site is higher than that of the Kino study site which is suitable for the performance of yield and yield components of different malt barley varieties. The result of this study is in accordance with Abdoli and Saeidil [26] who reported that significant differences were found among varieties in terms of the number of kernels per spike. Similarly, this result agrees with that obtained by other authors (Ryan et al. [27]; Gezahegne and Kefale [22]; and Abebe [24]) who testified that the distinction of number of kernels per spike is a purpose of barley genotype. Moreover, Laghari et al.'s [28] result showed important alteration among three varieties of wheat on number of kernels per spike and 1000 kernel weight. Stapper and Fischer [29] and Singh et al. [30] also described related outcomes, and the current result also agrees with Knezevic et al. [31] who determined that genotype and location have inspiration to distinction of number of kernels per spike. However, the current result is in contrast with Valerio et al. [32] who stated that the wheat genotypes did not influence the number of grains per ear obtained in distinct seeding densities.

3.5. Effective Tiller Number. The number of effective tillers is the most important yield donating limit, for the reason that the final economic yield of most of the cereals is determined by the number of fertile or effective tillers. Analysis of variance indicated that the main effect of varieties, inter-row spacing, and locations significantly $(p<0.01)$ influenced the effective tiller number. The interaction effect of inter-row spacing with varieties on the effective tiller number was also significant, while the interaction effect of variety, location, and inter-row spacing was not significant (Table 3). The effect of varieties with inter-row spacing interaction mean showed that the maximum number $(84.083,85.433)$ of effective tillers was obtained from EH 1847 variety with $25 \mathrm{~cm}$ and $30 \mathrm{~cm}$ row spacing which are nonsignificant from each other followed by Sabine (83.167) and Holker (83.667) varieties with 25 and $30 \mathrm{~cm}$, respectively. The minimum number (49 and 49.167) of effective tillers was also recorded from Fregebse and Ibon varieties with $20 \mathrm{~cm}$ row spacing (Table 4). This might be due to the genetic characteristics of malt barley varieties that determine the number of effective tillering capacity and inter-row spacing which is also another factor for effectiveness of fertile tiller. The optimum interrow spacing gives maximum number of effective tiller, whereas narrow inter row spacing gives limited or minimum amount of effective tiller number due to the competition of available nutrients. This result is in agreement with that of
Suleiman et al. [33] and Abebe [24] who reported that malt barley varieties have significant difference for tillering. Likewise, Alemu [16] stated that, at wider plant spacing, the malt barley crops produced a higher number of tillers per plant, because the competitions among the plant for natural resources are very low. Furthermore, Patel and Meena [34] also reported a similar result.

3.6. Spike Length. Spike length is one of the important yield contributing components. It is directly associated with yield. It has been found that a spike with more length bears more number of the grains. Therefore, any change in spike length will have a direct impact on yield [34].

The statistical analysis results showed that the main effect of varieties and location on spike length of malt barley was significant $(p<0.01)$. The interaction effect of location, variety, and inter-row spacing was also significant $(p<0.01)$. However, the interaction effect of variety with inter-row spacing was nonsignificant on the spike length (Table 1). The interaction mean of variety, location, and inter-row spacing presented in (Table 5) showed that the maximum number $(7.26 \mathrm{~cm})$ of spike length was recorded from EH1847variety with $20 \mathrm{~cm}$ inter-row spacing at the Milligebsa study site followed by Ibon 174/3, Hollker with $20 \mathrm{~cm}$ inter-row spacing, and HB1963 with 30 and $25 \mathrm{~cm}$ inter-row spacing at the Milligebsa study site, which were statistically at par with each other. While the minimum number $(5.28 \mathrm{~cm}$ and $5.4533 \mathrm{~cm}$ ) of spike length was recorded from Freygebse variety with $25 \mathrm{~cm}$ and $30 \mathrm{~cm}$ inter-row spacing followed by EH1847 variety $(5.3333 \mathrm{~cm}$ and $5.3867 \mathrm{~cm})$ of spike length with $20 \mathrm{~cm}$ and $25 \mathrm{~cm}$ inter-row spacing at the Kino study site (Table 5). This might be because of the influence of environment with different genetic characteristics of the varieties. In other wards, different varieties have different capacities for adaptation of different environmental conditions, and finally, the result of yield and their components may be quite different. These findings were in line with the results reported by Mali [35]. The current result is also in agreement with that of Shahzad et al. [20] who stated that the varietal difference in spike length is administered by genetic makeup of the genotype and the environmental consequence.

\subsection{Interaction Effects of Varieties and Inter-Row Spacing on} Thousand Kernel Weight. The analysis of variance showed that the interaction effect of inter-row spacing with variety was significant $(p<0.01)$. However, the three-way interaction (variety, location, and inter-row spacing) was not affected thousand kernel weight (Table 1).The mean result of varieties with inter-row spacing interaction indicated that the maximum numbers $(53.333,52.833$, and $52.5 \mathrm{gm})$ of thousand kernel weight were recorded from the Sabine variety with 20,30 , and $25 \mathrm{~cm}$ inter-row spacing, respectively, which were nonsignificant with each other. While the minimum numbers (42.292 and $46.333 \mathrm{gm}$ ) of thousand kernel weight was recorded from Ibone variety with 20 and $25 \mathrm{~cm}$ inter-row spacing, respectively, followed by Holker and Freygebse varieties with $20 \mathrm{~cm}$ inter-row spacing 
TABLE 4: Interaction effect of varieties with inter-row spacing on effective tiller number of malt barley at Debark, north Gondar, Ethiopia, in 2019.

\begin{tabular}{lccr}
\hline Varieties & & \multicolumn{2}{c}{$\begin{array}{c}\text { Effective tiller number } \\
\text { Inter-row spacing }\end{array}$} \\
\hline HB1963 & 20 & 25 & 30 \\
Holker & 67.917 & 75.500 & 69.917 \\
Freygebse & 72.667 & 74.500 & 83.667 \\
Sabine & 49.000 & 68.500 & 68.917 \\
EH 1847 & 60.583 & 83.167 & 65.583 \\
Ibone & 72.500 & 84.083 & 85.433 \\
LSD & 49.167 & 82.167 & 69.833 \\
CV & & 12.206 & 14.87 \\
\hline
\end{tabular}

$\mathrm{LSD}=$ list significant difference; $\mathrm{CV}=$ coefficient of variation.

TABLE 5: Interaction effect of varieties, inter-row spacing, and location on spike length of malt barley at Debark, north Gondar, Ethiopia, in 2019.

\begin{tabular}{|c|c|c|c|c|c|c|c|}
\hline \multirow{3}{*}{ Location } & \multirow{3}{*}{ Inter-row spacing } & \multicolumn{6}{|c|}{ Spike length $(\mathrm{cm})$} \\
\hline & & \multicolumn{6}{|c|}{ Varieties } \\
\hline & & HB 1963 & Holker & Freygebs & Sabine & EH 1847 & Ibone $174 / 03$ \\
\hline \multirow{4}{*}{ Milligebsa } & 20 & 6.5867 & 7.0600 & 6.0933 & 5.6133 & 7.2600 & 7.1667 \\
\hline & 25 & 6.9467 & 6.6400 & 6.7133 & 6.1667 & 6.8733 & 6.7600 \\
\hline & 30 & 6.9600 & 6.8933 & 5.7467 & 5.9733 & 7.0067 & 6.7867 \\
\hline & 20 & 6.3800 & 6.4200 & 5.7800 & 6.4067 & 5.3333 & 5.5800 \\
\hline \multirow[t]{2}{*}{ Kino } & 25 & 6.3267 & 6.8000 & 5.2800 & 6.6533 & 5.3867 & 6.6400 \\
\hline & 30 & 5.8467 & 6.4467 & 5.4533 & 6.7467 & 5.3600 & 6.8933 \\
\hline LSD & & & & 0.6296 & & & \\
\hline $\mathrm{CV}$ & & & & 6.08 & & & \\
\hline
\end{tabular}

LSD = list significant difference; $C V=$ coefficient of variation.

(Table 6). This result may be due to the tendency of the experimental tested malt barley varieties which gives a different number of thousand kernel weight at different inter-row spacing. Kedir et al. [36] and Abebe [24] determined similar results.

3.8. Interaction Effects of Varieties, Inter-Row Spacing, and Location on Biological Yield. The analysis of variance revealed that the interaction effect of variety, inter-row spacing, and location had significantly $(p<0.01)$ influenced the biological yield (Table 1). The interaction mean result showed that the maximum number $(25218 \mathrm{~kg}$ and $22064 \mathrm{~kg}$ ) of biological yield was recorded from HB1963 and Holker varieties with $25 \mathrm{~cm}$ inter-row spacing at the Milligebsa study site, respectively, which were significant with each other. While the minimum number $(4621 \mathrm{~kg}$ and $5731 \mathrm{~kg})$ of biological yield was recorded from Freygebse variety with $20 \mathrm{~cm}$ inter-row spacing and HB1963 variety with $30 \mathrm{~cm}$ inter-row spacing at Kino study site, respectively, which were nonsignificant with each other (Table 7). There was also a significant variation between the other experimental tested varieties with different inter-row spacing at both study sites. This result difference might be due to the genetic characteristics of the varieties that are responsible for different inter-row spacing at different locations and also the agro- ecological difference, and the soil fertility status of the study site was affected the biological yield. That means, at Milligebsa study site, the altitude range is very high, relative to Kino study site; this results in the growth stage of the crop to be late and accumulates maximum dry matter production by the higher rate of photosynthesis activities which leads to maximum biological yield. The current result is in agreement with that of Alemayehu et al.'s[37] who determined that the variety of barley ecologies is high with a large number of widespread varieties and outdated ones existing in Ethiopia, which allows the crop to be more adaptable in highlands.

3.9. Interaction Effects of Varieties, Inter-Row Spacing, and Location on Grain Yield. The analysis of variance indicated that the interaction effect of variety, inter-row spacing, and location (three-way interaction) was highly significant $(p<0.01)$ (Table 1$)$. The mean analysis data presented in (Table 8) showed that the maximum number $(5882.1 \mathrm{~kg}$, $5505.4 \mathrm{~kg}$, and $4851.2 \mathrm{~kg}$ ) of grain yield was recorded from HB1963, Holker, and Sabine varieties with $25 \mathrm{~cm}$ inter-row spacing at Milligebsa study site, respectively, which were significant with each other. While the minimum number $(1615.6 \mathrm{~kg}$ and $2073.4 \mathrm{~kg}$ ) of grain yield was recorded from Freygebse variety with 20 and $25 \mathrm{~cm}$ inter-row spacing at Kino study site, respectively, followed by $2240.7 \mathrm{~kg}$ of grain 
TABLE 6: Interaction effect of varieties with inter-row spacing and variety with location on thousand kernel weight of malt barley at Debark, north Gondar, Ethiopia, in 2019.

\begin{tabular}{lccr}
\hline Varieties & & \multicolumn{2}{c}{$\begin{array}{c}\text { Thousand kernel weight }(\mathrm{gm}) \\
\text { Inter-row spacing }(\mathrm{cm})\end{array}$} \\
\hline HB1963 & 20 & 25 & 54.400 \\
Holker & 52.083 & 53.833 & 50.083 \\
Freygebse & 48.567 & 50.125 & 52.083 \\
Sabine & 48.667 & 50.00 & 52.833 \\
EH 1847 & 53.333 & 52.500 & 51.333 \\
Ibone & 49.833 & 50.833 & 49.333 \\
LSD & 42.292 & 46.333 & 2.2050 \\
CV & & 3.79 & \\
\hline
\end{tabular}

$\mathrm{LSD}=$ list significant difference; $\mathrm{CV}=$ coefficient of variation.

TABLE 7: Interaction effect of varieties, inter-row spacing, and location on biological yield of malt barley at Debark, north Gondar, Ethiopia, in 2019.

\begin{tabular}{|c|c|c|c|c|c|c|c|}
\hline \multirow{3}{*}{ Location } & \multirow{3}{*}{ Inter-row spacing } & \multicolumn{6}{|c|}{ Biological yield $\left(\mathrm{kg} \mathrm{ha}^{-1}\right)$} \\
\hline & & \multicolumn{6}{|c|}{ Varieties } \\
\hline & & HB 1963 & Holker & Freygebse & Sabine & EH 1847 & Ibone174/3 \\
\hline \multirow{3}{*}{ Milligebsa } & 20 & 20429 & 19196 & 17196 & 14246 & 12607 & 14421 \\
\hline & 25 & 25218 & 22064 & 19936 & 16469 & 14276 & 17159 \\
\hline & 30 & 16729 & 18553 & 13813 & 17492 & 13808 & 15241 \\
\hline \multirow{3}{*}{ Kino } & 20 & 7872 & 7709 & 4621 & 8529 & 9650 & 7156 \\
\hline & 25 & 5921 & 8590 & 6931 & 9180 & 10537 & 11658 \\
\hline & 30 & 5731 & 13111 & 8011 & 9929 & 12683 & 6957 \\
\hline LSD & & & & 1506.7 & & & \\
\hline $\mathrm{CV}$ & & & & 7.18 & & & \\
\hline
\end{tabular}

$\mathrm{LSD}=$ list significant difference; $\mathrm{CV}=$ coefficient of variation.

TABLE 8: Interaction effect of varieties, inter-row spacing, and location on grain yield of malt barley at Debark, north Gondar, Ethiopia, in 2019.

\begin{tabular}{|c|c|c|c|c|c|c|c|}
\hline \multirow{3}{*}{ Location } & \multirow{3}{*}{ Inter-row spacing } & \multicolumn{6}{|c|}{ Grain yield $\left(\mathrm{kg} \mathrm{ha}^{-1}\right)$} \\
\hline & & \multicolumn{6}{|c|}{ Varieties } \\
\hline & & HB1963 & Holker & Freygebse & Sabine & EH 1847 & Ibone $174 / 3$ \\
\hline \multirow{3}{*}{ Milligebsa } & 20 & 4716.3 & 4901.5 & 3963.4 & 4234.9 & 4118.1 & 3782.4 \\
\hline & 25 & 5882.1 & 5505.4 & 4223.1 & 4851.2 & 4524.6 & 4779.5 \\
\hline & 30 & 4283.3 & 4765.6 & 3576.3 & 4786.4 & 3492.7 & 4391.3 \\
\hline \multirow{3}{*}{ Kino } & 20 & 3296.7 & 2633.0 & 1615.6 & 2753.3 & 3896.7 & 3154.3 \\
\hline & 25 & 2368.0 & 2329.7 & 2073.4 & 2947.7 & 3268.2 & 4375.0 \\
\hline & 30 & 2240.7 & 4420.7 & 3395.7 & 3445.0 & 4203.0 & 2855.7 \\
\hline LSD & & & & 316.37 & & & \\
\hline $\mathrm{CV}$ & & & & 5.14 & & & \\
\hline
\end{tabular}

$\mathrm{LSD}=$ list significant difference; $\mathrm{CV}=$ coefficient of variation.

yield recorded from HB1963 variety with $30 \mathrm{~cm}$ inter-row spacing at Kino study site. There was also a significant variation among the means of other varieties with different inter-row spacing at both study sites (Table 8). These result differences might be due to the genetic characteristics of the varieties that gave different amounts of grain yield with different inter-row spacing and location or altitude difference in the study sites. These results agree with those of
Jairus et al. [38] who found significant differences in maltable grain among varieties and across some locations. In addition, this result is also in line with that of Aynewa et al. [39] who determined that barley varieties showed different capacities to adapt different environments. This can lead to differences in yield and quality components with more fertile tillers per plant and number of kernels per spike making major contributions to yield [40]. Furthermore, O’Donovan 
et al. [41] found that highly significant differences among varieties, environment, and variety by environment interaction, although the ranking across environments was not consistent, showing varying stabilities among varieties with respect to grain yield. These large differences could be associated with the relatively high heritability of varieties [42]. Moreover, the current result also agrees with that of Hussain et al. [43] who reported that the grain yield was significantly influenced by the interaction of different row spacing with different crop varieties. Likewise, the grain yield and yield relating characters in barley shows variation in different degrees, and this difference is accompanied by their genetic materials, agronomic practices like spacing, and effects of environmental factors [44].

\subsection{Interaction Effects of Varieties, Inter-Row Spacing, and} Location on Straw Yield. The current study analysis result revealed that the interaction effects of variety, inter-row spacing, and location (three way interaction) on straw yield were significant $(p<0.01)$ (Table 1$)$. The interaction mean analysis result of variety, inter-row spacing, and location showed that the maximum number $(19336 \mathrm{~kg}$ and $16559 \mathrm{~kg}$ ) of straw yield was recorded from HB1963 and Holker varieties with $25 \mathrm{~cm}$ inter-row spacing at Milligebsa study site, respectively, which were statistically significant with each other. While the minimum number $3490 \mathrm{~kg}$ and $3553 \mathrm{~kg}$ of straw yield was obtained from HB1963 variety with 30 and $25 \mathrm{~cm}$ inter-row spacing, respectively, at Kino study site followed by Ibone variety with $30 \mathrm{~cm}$ inter-row spacing at Kino study site which gave $4102 \mathrm{~kg}$ of straw yield. Variety Holker gave maximum straw yield at Kino study site with $30 \mathrm{~cm}$ inter-row spacing. There was also a significant variation among the other experimental tested variety with different inter-row spacing at both study sites (Table 9). These might be due to the genetic potential of the varieties, the environmental effect, and the other agronomic practices like inter-row spacing which are responsible combined factors that lead to give different amounts of straw yield.

3.11. Correlation Analysis. Grain yield is the most complex trait of food barley and influenced by genetic and environmental factors that determine productivity of the varieties. The analysis correlation affords the evidence of association among the important crop characters and hence leads to a guiding model for direct and indirect enhancement in grain yield [45]. Therefore, understanding of interrelationships of grain yield and other traits is highly important for formulating the selection criteria to higher yields. The correlation coefficient among yield and yield components is presented in Table 10. Grain yield was positively and significantly associated with phonological parameters such as days to $50 \%$ heading $\left(r=0.58^{* *}\right)$ and $90 \%$ days to physiological maturity $\left(r=0.58^{* *}\right)$. This suggests that grain yield will increase at the longest maturity period [46].
Similarly, grain yield was positively and significantly associated with growth parameters like plant height $\left(r=0.38^{* *}\right)$, effective tillers number $\left(r=0.80^{* *}\right)$, spike length $\left(r=0.30^{* *}\right)$, number of kernels per spike $\left(r=0.34^{* *}\right)$, biomass yield $\left(r=0.88^{* *}\right)$, thousand seed weight $\left(r=0.43^{* *}\right)$, and straw yield $\left(r=0.83^{* *}\right)$ (Table 10$)$. These indicated that the yield increase is attributed to an increase in plant height, effective tiller number, and spike length, number of kernels per spike, and biomass yield. A positive relationship between grain yield and growth parameters was also reported in barley in [46] which stated that the grain yield was positively and significantly associated with plant height, spike length, total tillers, number of fertile tillers, biomass yield, straw yield, and thousand kernels weight. Likewise, Bishaw et al. [47] also reported that a positive association between biomass yield and plant height. In addition, Abebe and Manchore [48] reported similar results.

3.12. Summary and Conclusion. The production and productivity of malt barley in north Gondar are low due different factors. The use of broadcast sowing and local low yielding varieties are the major factors in the study area. This indicates the need to conduct research and determine the optimum inter-row spacing and high-yielding improved varieties for maximum productivity of malt barley crop. Therefore, this study was conducted in north Gondar, Ethiopia, to investigate response of malt barley varieties to different row spacing for the growth, yield, and yield components under contrasted environment with the objective to evaluate the effect of inter-row spacing on the growth, yield, and yield components of malt barley varieties.

The results of this study indicated that days to $50 \%$ heading, days to $90 \%$ physiological maturity, plant height, spike length, and number of kernel per spike were significantly $(p<0.01)$ affected by the main effect of location and varieties. The main effect of variety, inter-row spacing, and location also highly significantly $(p<0.01)$ affects the effective tiller number, biomass yield, grain yield, and straw yield. Moreover, the interaction effect of variety, inter-row spacing, and location (3-way interaction) also affected days to $50 \%$ heading, spike length, biomass yield, grain yield, and straw yield at $p<0.01$ significant level. Whereas days to $90 \%$ physiological maturity, effective tiller number, and thousand kernel weight were affected by the interaction effect of location and variety at $p<0.01$ level of significance. In addition, the interaction effect of variety with inter-row spacing also affects the effective tiller number at $p<0.05$ level of significance and thousand kernel weight at $p<0.01$ level of significance.

Therefore, based on the results of yield and yield component parameters, malt barley varieties (HB1963, Hollker, and Sabine) sown at inter-row spacing of $25 \mathrm{~cm}$ had better yield and yield component at potential environment (Milligebsa experimental site) rather than kino experimental site. 
TABLE 9: Interaction effect of varieties, inter-row spacing, and location on straw yield of malt barley at Debark, north Gondar, Ethiopia, in 2019.

\begin{tabular}{|c|c|c|c|c|c|c|c|}
\hline \multirow{3}{*}{ Location } & \multirow{3}{*}{ Inter-row spacing } & \multicolumn{6}{|c|}{ Straw yield $\left(\mathrm{kg} / \mathrm{ha}^{-1}\right)$} \\
\hline & & \multicolumn{6}{|c|}{ Varieties } \\
\hline & & HB 1963 & Holker & Freygebs & Sabine & EH 1847 & Ibone $174 / 03$ \\
\hline \multirow{4}{*}{ Milligebsa } & 20 & 15712 & 14295 & 13233 & 10011 & 8489 & 10639 \\
\hline & 25 & 19336 & 16559 & 15713 & 11618 & 9751 & 12380 \\
\hline & 30 & 12446 & 13788 & 10237 & 12705 & 10316 & 10850 \\
\hline & 20 & 4575 & 5076 & 3006 & 5776 & 5753 & 4002 \\
\hline \multirow[t]{2}{*}{ Kino } & 25 & 3553 & 6261 & 4858 & 6232 & 7269 & 7283 \\
\hline & 30 & 3490 & 8690 & 4616 & 6484 & 8480 & 4102 \\
\hline LSD & & & & 1516.2 & & & \\
\hline $\mathrm{CV}$ & & & & 10.23 & & & \\
\hline
\end{tabular}

$\mathrm{LSD}=$ list significant difference; $\mathrm{CV}=$ coefficient of variation.

TABLE 10: Simple correlation analysis among growth, yield, and yield component parameters of malt barley at Debark, north Gondar, Ethiopia, in 2019.

\begin{tabular}{|c|c|c|c|c|c|c|c|c|c|c|}
\hline $\mathrm{X}$ & $50 \% \mathrm{H}$ & $90 \% \mathrm{PM}$ & $\mathrm{PH}$ & NKPS & SL & ETN & $\mathrm{BIO}$ & GY & SY & TKW \\
\hline $50 \% \mathrm{H}$ & 1 & $0.894^{* *}$ & $0.373^{* *}$ & $0.308^{* *}$ & $0.434^{* *}$ & $0.637^{* *}$ & $0.745^{* *}$ & $0.582^{* *}$ & $0.759^{* *}$ & $0.262^{* *}$ \\
\hline $90 \% \mathrm{M}$ & & 1 & $0.343^{* *}$ & $0.389^{* *}$ & $0.357^{* *}$ & $0.659^{* *}$ & $0.731^{* *}$ & $0.583^{* *}$ & $0.742^{* *}$ & $0.405^{* *}$ \\
\hline $\mathrm{PH}$ & & & 1 & $0.218^{*}$ & $0.202^{*}$ & $0.510^{* *}$ & $0.461^{* *}$ & $0.378^{* *}$ & $0.465^{* *}$ & $0.116^{\mathrm{NS}}$ \\
\hline NKPS & & & & 1 & $0.393^{* *}$ & $0.338^{* *}$ & $0.349^{* *}$ & $0.338^{* *}$ & $0.340^{* *}$ & $0.220^{*}$ \\
\hline SL & & & & & 1 & $0.414^{* *}$ & $0.361^{* *}$ & $0.303^{* *}$ & $0.363^{* *}$ & $0.159^{\mathrm{NS}}$ \\
\hline ETN & & & & & & 1 & $0.827^{* *}$ & $0.807^{* *}$ & $0.805^{* *}$ & $0.230^{*}$ \\
\hline BY & & & & & & & 1 & $0.888^{* *}$ & $0.984^{* *}$ & $0.073^{\mathrm{NS}}$ \\
\hline GY & & & & & & & & 1 & $0.833^{* *}$ & $0.003^{\mathrm{NS}}$ \\
\hline SY & & & & & & & & & 1 & $0.087^{\mathrm{NS}}$ \\
\hline TKW & & & & & & & & & & 1 \\
\hline
\end{tabular}

${ }^{*}$ Correlation is significant at the 0.05 level (2-tailed), ${ }^{* *}$ correlation is significant at the 0.01 level (2-tailed), NS $=$ nonsignificant, $50 \% \mathrm{H}=50 \%$ heading, $90 \%$ $\mathrm{PM}=90 \%$ physiological maturity, $\mathrm{PH}=$ plant height, $\mathrm{NKPS}=$ number of kernels per spike, $\mathrm{SL}=$ spike length, $\mathrm{ETN}=$ effective tillers number, $\mathrm{BY}=$ biomass yield, GY = grain yield, TKW = thousand kernels weight, $\mathrm{SY}=$ straw yield.

\section{Data Availability}

The data used to support the findings of this study are available from the corresponding author upon request.

\section{Conflicts of Interest}

The authors declare that there are no conflicts of interest.

\section{Acknowledgments}

This research was funded by Debark University, Ethiopia. We are grateful to the fund provide by Debark University. We express our sincere gratitude to the Adet Agriculture Research center for providing us with improved malt barley variety seeds. Moreover, our sincere thanks also go to Milligebsa and Kino Keble agriculture development agents for their notable support during the research for arranging the experimental land from the farmers.

\section{References}

[1] T. Mulualem and Z. Bekeko, "Diversity and conservation of wild crop relatives for source of resistance to major biotic stress: experiences in Ethiopia," Journal of Genetic and Environmental Resources Conservation, vol. 2, no. 3, pp. 331-348, 2014.
[2] B. Lake, H. Gebre, and F. Alemayehu, "Barley research in Ethiopia: past work and future prospects," in Proceedings of the First Barley Research Review Workshop, IAR/ICARDA, Addis Ababa, Ethiopia, October 1993.

[3] P. Giraldo, E. Benavente, F. Manzano-Agugliaro, and E. Gimenez, "Worldwide research trends on wheat and barley: a bibliometric comparative analysis," Agronomy, vol. 9, no. 7, p. 352, 2019.

[4] Central Statistical Agency (CSA), Agricultural Sample Survey, Report on Area and Production of Major Crops, CSA, Addis Ababa, Ethiopia, 2019.

[5] S. Grando and H. G. Macpherson, "Food barley: importance, uses and local knowledge," in Proceedings of the International Workshop on Food Barley Improvement, International Center for Agricultural Research in the Dry Areas (ICARDA), Hammamet, Tunisia, January 2002.

[6] T. Deressa, R. Hassan, and D. Poonyth, "Measuring the impact of climate change on South African agriculture: the case of sugarcane growing regions," Agrekon, vol. 44, no. 4, pp. 524-542, 2005.

[7] International Center for Agricultural Research in the Dry Areas (ICARDA), 2008, http://www.icarda.org/publications/ Donors/Ethiopia/G-Barley.htm.

[8] B. Mulatu and B. Lakew, Barley Research and Development in Ethiopia-An Overview, p. 1, ICARDA, Beirut, Lebanon, 2011.

[9] H. Mohammed and L. Getachew, "An overview of malt barley production and marketing in ARSI," in Proceedings of the 
Workshop on Constraints and Prospects of Malt Barley, vol. 15, pp. 1-25, Nazereth, Ethiopia, March 2003.

[10] S. Farooq, M. Shahid, M. B. Khan, M. Hussain, and M. Farooq, "Improving the productivity of bread wheat by good management practices under terminal drought," Journal of Agronomy and Crop Science, vol. 201, no. 3, pp. 173-188, 2015.

[11] I. I. Ibeawuchi, E. Matthews-Njoku, M. O. Ofor, C. P. Anyanwu, and V. N. Onyia, "Plant spacing, dry matter accumulation and yield of local and improved maize cultivars," Journal of American Science, vol. 4, no. 1, pp. 545-1003, 2008.

[12] T. K. Das and N. T. Yaduraju, "Effects of missing-row sowing supplemented with row spacing and nitrogen on weed competition and growth and yield of wheat," Crop and Pasture Science, vol. 62, no. 1, pp. 48-57, 2011.

[13] S. K. Bhowmik, M. A. R. Sarkar, and F. Zaman, "Effect of spacing and number of seedlings per hill on the performance of aus rice cv. NERICA 1 under dry direct seeded rice (DDSR) system of cultivation," Journal of the Bangladesh Agricultural University, vol. 10, no. 2, pp. 191-196, 2012.

[14] G. Ayana, A. Abdo, Y. Merine et al., "Plant variety release. Protection and Seed Quality Control Directorate," Plant Biotechnology and Plant Protection, vol. 3, pp. 96-98, 2016.

[15] Statistical Analysis Software (SAS) Institute, SAS Version 9.2 (C) 2002-2003, SAS Institute, Inc., Cary, NC, USA, 2003.

[16] B. Alemu, "Effect of intra row-spacing on malt barley varieties (Hordeum vulgare $L$ ) on performance at gitilo research site and JarteWerdas farmers' field, Western Ethiopia," International Journal of Advanced Research, vol. 5, no. 5, 1971.

[17] A. Adinew, "Effect of seed sources and rates on productivity of bread wheat (Triticum aestivum L.) varieties at Kersa, eastern Ethiopia," Journal of Equity in Sciences and Sustainable Development (JESSD), vol. 3, no. 1, pp. 64-75, 2019.

[18] D. Terefe, T. Desalegn, and H. Ashagre, "Effect of nitrogen fertilizer levels on grain yield and quality of malt barley (Hordeum vulgare L.) varieties at Wolmera District, Central Highland of Ethiopia," International Journal of Research Studies in Agricultural Sciences4, vol. 4, pp. 29-43, 2018.

[19] W. G. Abtew, B. Lakew, B. I. Haussmann, and K. J. Schmid, "Ethiopian barley landraces show higher yield stability and comparable yield to improved varieties in multi-environment field trials," Journal of Plant Breeding and Crop Science, vol. 7, no. 8, pp. 275-291, 2015.

[20] M. A. Shahzad, S. T. Sahi, M. M. Khan, and M. Ahmad, "Effect of sowing dates and seed treatment on grain yield and quality of wheat," Pakistan Journal of Agricultural Sciences (Pakistan), vol. 44, pp. 581-583, 2007.

[21] S. Geng, "Effect of variety and environment on head rice yield," in Proceedings of the 5th Annual Report to the California Rice Growers, Food and Agricultural State of California, Sacramento, CA, USA, 1984.

[22] B. Gezahegn and D. Kefale, "Effect of nitrogen fertilizer level on grain yield and quality of malt barley varieties in Malga Woreda, Southern Ethiopia," Food Science, vol. 52, 2016.

[23] A. Jemal, T. Tamado, and E. Firdissa, "Response of bread wheat (Triticum aestivum L.) varieties to seeding rates at Kulumsa, South Eastern Ethiopia," Asian Journal of Plant Sciences, vol. 14, no. 2, pp. 50-58, 2015.

[24] A. Abebe, "Effects of blended fertilizer rates on growth, yield and quality of malt barley (Hordeum distichum L.) varieties at Debre Berhan district central high land of Ethiopia," MSc thesis Debre Berhan University, Debre Berhan, Ethiopia, 2018.
[25] A. R. Shahwani, S. U. Baloch, S. K. Baloch et al., "Influence of seed size on germinability and grain yield of wheat (Triticum aestivum L.) varieties," Journal of Natural Sciences Research, vol. 4, no. 23, pp. 147-155, 2014.

[26] M. Abdoli and M. Saeidi, "Effects of water deficiency stress during seed growth on yield and its components, germination and seedling growth parameters of some wheat cultivars," International Journal of Agriculture and Crop Sciences, vol. 4, no. 15, pp. 1110-1118, 2012.

[27] J. Ryan, M. Abdel Monem, and A. Amri, "Nitrogen fertilizer response of some barley varieties in semi-arid conditions in Morocco," Journal of Agricultural Science and Technology, vol. 11, no. 2, pp. 227-236, 2009.

[28] G. M. Laghari, F. C. Oad, T. Shamasuddin et al., "Growth, yield and nutrient uptake of various wheat cultivars under different fertilizer regimes," Sarhad Journal of Agriculture, vol. 26, no. 4, pp. 489-497, 2010.

[29] M. Stapper and R. Fischer, "Genotype, sowing date and plant spacing influence on high-yielding irrigated wheat in southern New South Wales. II. Growth, yield and nitrogen use," Australian Journal of Agricultural Research, vol. 41, no. 6, pp. 1021-1041, 1990.

[30] A. Singh, R. D. Singh, and R. P. Awasthi, "Organic and inorganic sources of fertilizers for sustained productivity in rice (Oryza sativa)--Wheat (Triticum aestivum L.) sequence on humid hilly soils of Sikkim," Indian Journal of Agronomy, vol. 41, no. 2, pp. 191-194, 1996.

[31] D. Knezevic, V. Zecevic, S. Stamenkovic, S. Atanasijevic, and B. Milosevic, "Variability of number of kernels per spike in wheat cultivars (Triticum aestivum L.)," Journal of Central European Agriculture, vol. 13, no. 3, 2012.

[32] I. P. Valério, F. I. F. D. Carvalho, G. Benin et al., "Seeding density in wheat: the more, the merrier?" Scientia Agricola, vol. 70, no. 3, pp. 176-184, 2013.

[33] A. A. Suleiman, J. F. Nganya, and M. A. Ashraf, "Correlation and path analysis of yield and yield components in some cultivars of wheat (Triticum aestivum L.) in Khartoum State, Sudan," Journal of Forest Products \& Industries, vol. 3, no. 6, pp. 221-228, 2014.

[34] N. A. Patel and M. Meena, "Relative performance of barley (Hordeum vulgare L.) cultivars under saline water condition," International Journal of Current Microbiology and Applied Sciences, vol. 7, no. 10, pp. 1724-1733, 2018.

[35] H. Mali, Performance of Barley (Hordeum Vulgare L.) Varieties under Varying Precision Nutrient Management Practices, Doctoral Dissertation, MPUAT, Udaipur, India, 2016.

[36] A. Kedir, O. Chimdesa, S. Alemu, and Y. Tesfaye, "Adaptability study of malt barley varieties at high land of Guji Zone, Southern Oromia," Journal of Biology, Agriculture and Healthcare, vol. 6, no. 13, 2016.

[37] F. Alemayehu, B. Bekele, F. Tufa, A. Nuramo, and T. Getachew, "Malting barley breeding," in Proceedings of the Barly Research Review Workshop, IAR/ICARDA, Addis Abeba, Ethiopia, October 1993.

[38] O. J. Jairus, P. E. O. Auma, and D. L. Ngode, "Evaluation of promising malting barley varieties using agronomic and quality traits in Kenya," Journal of Agriculture \& Life Sciences, vol. 2, no. 1, pp. 104-110, 2015.

[39] Y. Aynewa, T. Dessalegn, and W. Bayu, "Participatory evaluation of malt barley (Hordeum vulgare L.) genotypes for yield and other agronomic traits at North-West Ethiopia," Wudpecker Journal of Agricultural Research, vol. 2, no. 8, pp. 218-222, 2013. 
[40] J. A. Al-Tabbal and A. H. Al-Fraihat, "Genetic variation, heritability, phenotypic and genotypic correlation studies for yield and yield components in promising barley genotypes," Journal of Agricultural Science, vol. 4, no. 3, p. 193, 2012.

[41] J. T. O’Donovan, T. K. Turkington, M. J. Edney et al., "Seeding rate, nitrogen rate, and cultivar effects on malting barley production," Agronomy Journal, vol. 103, no. 3, pp. 709-716, 2011.

[42] R. W. May, A. Qayyum, S. Liaqat et al., "Variability, heritability and genetic advance for some yield and yield related traits in barley (Hordeum vulgare L.) genotypes in arid conditions," Journal of Food, Agriculture \& Environment, vol. 10, no. 3-4, pp. 626-629, 2012.

[43] M. Hussain, Z. Mehmood, M. B. Khan, S. Farooq, L. Dong-Jin, and M. Farooq, "Narrow row spacing ensures higher productivity of low tillering wheat cultivars," International Journal of Agriculture and Biology, vol. 14, no. 3, 2012.

[44] M. H. Karim and M. A. Jahan, "Comparative study of yield and yield contributing traits of different genotypes in bread wheat," Journal of Agricultural and Biological Science, vol. 8, no. 2, pp. 147-151, 2013.

[45] M. D. Khan and I. H. Khalil, "Genetic divergence and association for yield and related traits inmash bean," Sarhad Journal of Agriculture (Pakistan), vol. 20, pp. 555-561, 2004.

[46] W. F. Bizuneh and D. A. Abebe, "Malt barley (Hordeum distichon L.) varieties performance evaluation in North Shewa, Ethiopia," African Journal of Agricultural Research, vol. 14, no. 8, pp. 503-508, 2019.

[47] Z. Bishaw, P. C. Struik, and A. J. Van Gastel, “Assessment of on-farm diversity of wheat varieties and landraces: evidence from farmers' fields in Ethiopia," African Journal of Agricultural Research, vol. 9, no. 39, pp. 2948-2963, 2014.

[48] B. Abebe and M. Manchore, "Effect of the rate of N fertilizer application on growth and yield of wheat (Triticum aestivum L.) at Chencha, Southern Ethiopia," International Journal of Plant, Animal and Environmental Sciences, vol. 6, no. 3, pp. 168-175, 2016. 